\title{
Relative growth of carcass tissues of goat kids from five breed types finished on pasture or feedlot
}

\section{Crescimento relativo dos tecidos da carcaça de cabritos de cinco grupos raciais terminados em pastagem ou confinamento}

\author{
Raquel Vasconcelos Lourençon ${ }^{1 *}$; Heraldo Cesar Gonçalves²; \\ Paulo Roberto de Lima Meirelles²; Richard Browning Junior ${ }^{3}$; \\ Maria Lenira Leite-Browning ${ }^{4}$; Andréia Cristina Toniolo Chávari ${ }^{1}$; \\ Raquel Ornelas Marques ${ }^{1}$; Gil Ignacio Lara Canizares ${ }^{1}$; Natalia Santos Leal ${ }^{5}$; \\ Helen Fernanda Barros Gomes ${ }^{6}$
}

\begin{abstract}
The aim of this study was to evaluate the effect of cross breeding, finishing system, and gender on the relative growth of carcass tissues of dairy kids. Seventy eight kids (39 male and 39 female) from five breed types were used: Alpine; $1 / 2$ Boer + 1/2 Alpine (1/2 BA); $1 / 2$ Nubian + 1/2 Alpine ( $1 / 2$ ANA); $3 / 4$ Boer + $1 / 4$ Alpine ( $3 / 4 \mathrm{BA})$; and $1 / 2$ Nubian $+1 / 4$ Boer $+1 / 4$ Alpine (TC). Kids were distributed into two finishing systems: in pasture with doe (FS1) and weaned in feedlot (FS2). Kids were slaughtered at a mean age of $128.4 \pm 7.9$ days and mean live weight of $22.07 \mathrm{~kg}$. The mean weight of half carcasses was $5.09 \mathrm{~kg}$. To determine allometric growth, we used the exponential equation $\mathrm{Y}=\mathrm{aX}{ }^{\mathrm{b}}$. In the half carcass, muscle tissue showed comparatively early growth in group $1 / 2 \mathrm{BA}$, whereas fat tissue of animals in FS1 had relatively late growth. Females exhibited early growth of muscle tissue, while in males this tissue was intermediate. The $1 / 2$ BA first-cross improved carcass characteristics by enhancing the growth of muscle tissue.
\end{abstract}

Key words: Allometry. Alpine. Boer. Finishing system. Nubian.

\section{Resumo}

Este trabalho foi realizado com o objetivo de avaliar a influência dos cruzamentos, sistema de terminação e sexo no crescimento relativo dos tecidos da carcaça de cabritos em crescimento. Foram utilizados 78 cabritos, 39 machos e 39 fêmeas, de cinco grupos raciais: 13 cabritos Alpinos; $14 \frac{1}{2}$ Boer $+1 / 2$ Alpino $(1 / 2$ BA $) ; 151 / 2$ Anglo Nubiano + $1 / 2$ Alpino $(1 / 2$ ANA $) ; 18 \frac{3 / 4}{4}$ Boer + $1 / 4$ Alpino $(3 / 4$ BA $)$; e 18 1/2 Anglo Nubiano $+1 / 4$ Boer $+1 / 4$ Alpino (TC). Os grupos foram distribuídos em dois sistemas de terminação, cabrito em pastagem com a mãe (ST1) e cabrito desmamado em confinamento (ST2). Os animais foram abatidos em média aos $22,07 \mathrm{~kg}$ de peso vivo e $128,4 \pm 7,9$ dias. O peso médio das meias carcaças foi de $5,09 \mathrm{~kg}$. Para determinação do crescimento alométrico foi utilizada a equação exponencial Y

\footnotetext{
${ }^{1}$ Drs., Universidade Estadual Paulista, UNESP, Botucatu, SP, Brasil. E-mail: rvlzoo@hotmail.com; actoniolo@hotmail.com; ra_ ornelas@yahoo.com.br; inabra68@hotmail.com

2 Profs. Drs., UNESP, Botucatu, SP, Brasil. E-mail: heraldo@fmvz.unesp.br; prmeirelles@uol.com.br

3 Prof. Dr., Tennessee State University, TSU, Nashville, USA. E-mail: rbrowning@tnstate.edu

${ }^{4}$ Prof. Dr., Alabama A\&M University, Huntsville, USA. E-mail: ml10002@auburn.edu

5 Discente do Curso de Doutorado em Zootecnia, UNESP, Botucatu, SP, Brasil. E-mail: natalia.leal@uol.com.br

${ }^{6}$ Prof $^{\mathrm{a}} \mathrm{Dr}^{\mathrm{a}}$, Universidade Federal do Mato Grosso, UFMT, Sinop, MT, Brasil. E-mail: gomesh@ufmt.br

* Author for correspondence
} 
$=\mathrm{aX}{ }^{\mathrm{b}} . \mathrm{O}$ tecido muscular, em relação ao peso da meia carcaça, apresentou crescimento precoce no grupo $1 / 2$ BA. O tecido adiposo dos animais do ST1 foi depositado tardiamente. As fêmeas apresentaram crescimento precoce de tecido muscular, em relação ao peso da meia carcaça, enquanto nos machos tal comportamento foi intermediário. $\mathrm{O}$ cruzamento $1 / 2 \mathrm{BA}$ pode melhorar as características da carcaça em função de potencializar o crescimento do tecido muscular.

Palavras-chave: Alometria. Alpina. Anglo Nubiana. Boer. Sistema de terminação.

\section{Introduction}

The northeast region of Brazil accounts for about $92 \%$ of the country's goat herd, predominantly naturalized breeds raised for meat and skin, whereas the goat industry in southeastern Brazil produces mainly dairy products. Goat meat is a healthy alternative to meat from other ruminants due to its comparatively low content of fat, cholesterol, and saturated fatty acids, and goats can be a good source of income for milk producers as well (PEREIRA FILHO et al., 2008).

Producers of dairy goats have used breeds specialized for meat production for crossing with their dams in order to achieve complementarity between breeds and young animals available for slaughtering that have high carcass yield and better meat quality. According to Madruga et al. (2005), the efficiency of this process depends on the selected breed and the nutritional status of the animals. Browning Junior et al. (2012) indicated that breed of dam may have a greater effect on kid carcass traits than breed of sire.

According to Gomes et al. (2011), the use of Boer or Anglo Nubian males in crosses with either Alpine or Boer/Alpine crossbred females resulted in similar performance, suggesting that these are options for obtaining quality carcasses.

Some authors have reported that the Boer breed has superior carcass and performance characteristics (MONTE et al., 2007; PEREIRA FILHO et al., 2008), although another study found that Boer was not superior for carcass yield when compared to other meat producing breeds such as Kiko and Spanish (BROWNING JUNIOR et al., 2012).
Owens et al. (1993) reported that the animal growth curve is also affected by factors other than breed, including gender, nutrition, and management; thus, knowledge of how these factors affect the growth curve may contribute to the production of better quality carcasses and may reduce production costs. These authors also suggested that tissues grow and develop in stages, and that each tissue may exhibit early, intermediate, or late development in relation to the entire body. Dietary nutrient supply must be coordinated with this pattern of growth in order to maintain the best growth rate. There have been few allometric studies of the goat carcass, and thus it is important to provide more information in this regard in order to obtain better quality carcasses (YÁÑEZ et al., 2009; AL-OWAIMER et al., 2013). The objective of this study was to evaluate the effects of cross breeding, finishing system, and gender on the relative growth of the carcass tissues of dairy kids.

\section{Materials and Methods}

This study was approved by the local ethics committee under protocol number 417/08 (Sao Paulo State University, Brazil). Seventy-eight kids (39 non-castrated males and 39 females) from five breed types were used: Alpine, 13 kids; $1 / 2$ Boer + $1 / 2$ Alpine ( $1 / 2$ BA), 14 kids; $1 / 2$ Anglo Nubian + 1/2 Alpine ( $1 / 2$ ANA), 15 kids; $3 / 4$ Boer $+1 / 4$ Alpine (3/4 BA), 18 kids; and the triple cross $1 / 2$ Anglo Nubian $+1 / 4$ Boer $+1 / 4$ Alpine (TC), 18 kids. After birth, the kids remained in the pen along with their mothers, with available hay and concentrate ad libitum. At 60 days of age (approximately $14 \mathrm{~kg}$ ), they were distributed into two finishing systems: kids with 
does in pasture (FS1) and kids weaned in the feedlot (FS1) (Table 1).

Kids were obtained using 30 Alpine does (Group 1) and $201 / 2$ Boer $+1 / 2$ Alpine does (Group 2). In group 1, 10 does were mated with 2 Alpine bucks, 10 with 2 Boer bucks and 10 with 2 Anglo Nubian bucks. In group 2, 10 does were mated with 2 Boer bucks and 10 with 2 Anglo Nubian bucks.

Kids were obtained using 30 Alpine does (Group 1) and $20 \frac{1}{2}$ Boer $+1 / 2$ Alpine does (Group 2). In group 1, 10 does were mated with 2 Alpine bucks, 10 with 2 Boer bucks and 10 with 2 Anglo Nubian bucks. In group 2, 10 does were mated with 2 Boer bucks and 10 with 2 Anglo Nubian bucks.

Table 1. Distribution of animals according to breed type, finishing system, and gender.

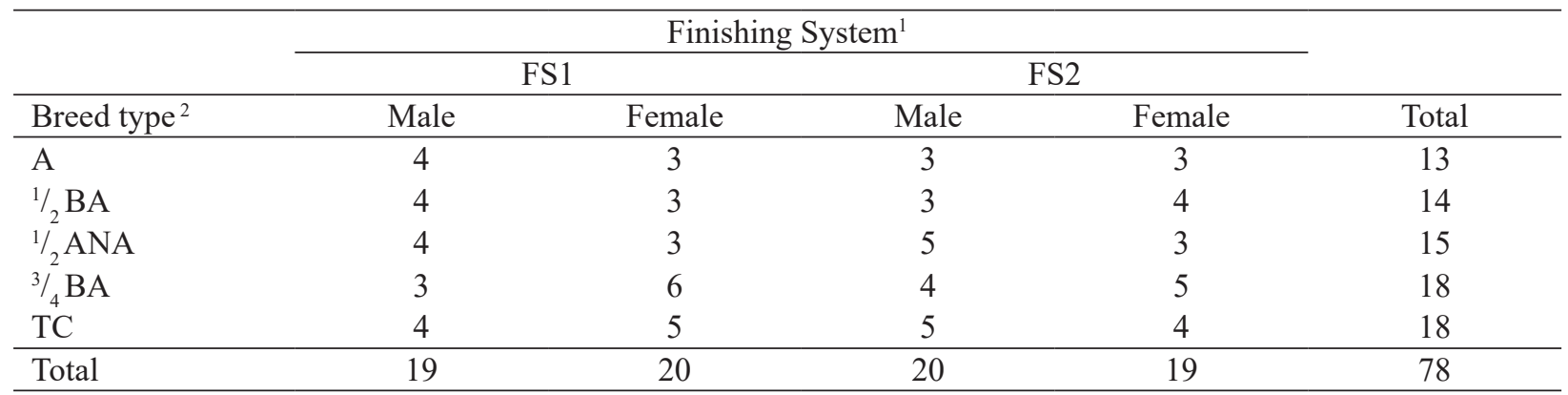

${ }^{1}$ Finishing systems: FS1, kids with does in pasture; FS2, kids weaned in feedlot. ${ }^{2}$ Breed types: A (Alpine); $1 / 2$ BA ( $(1 / 2$ Boer $+1 / 2$ Alpine); $1 / 2$ ANA ( 112 Anglo Nubian + 1/2 Alpine); $3 / 4$ BA (3/4 Boer + 11/4 Alpine); TC (1/2 Anglo Nubian + 1/4 Boer $+1 / 4$ Alpine).

In FS1, kids remained in the pasture with their mothers from 9 am to $5 \mathrm{pm}$; after this period, they were collected in collective pens and received water and mineral salt. We used rotational grazing with a fixed stocking rate of 11 paddocks of $550 \mathrm{~m}^{2}$ with three days of occupation and 30 days of rest. The forage species used was the grass Tobiatã (Panicum maximum cv. Tobiatã).

In FS2, kids were weaned at 60 days and sent to a feedlot where they received a complete diet provided ad libitum twice a day, consisting of $30 \%$ oat hay, 30\% ground corn grain, 28\% soybean meal, $8 \%$ wheat bran, $1 \%$ limestone, $1 \%$ dicalcium phosphate, and $2 \%$ mineral supplement, allowing remainings of $20 \%$ in the proportion of $30 \%$ forage and $70 \%$ concentrate. Analyses of the complete diet and forage (Table 2) were performed according to Silva and Queiroz (2002).
Table 2. Chemical composition of diets and forage consumed by male and female kids.

\begin{tabular}{|c|c|c|}
\hline Chemical composition & $\begin{array}{c}\text { Complete } \\
\text { diet }\end{array}$ & Forage \\
\hline Dry matter $(\%)$ & 94.59 & 24.31 \\
\hline Ash (\% DM) & 9.27 & 3.39 \\
\hline Crude protein $(\% \mathrm{DM})$ & 16.47 & 12.91 \\
\hline Ether extract (\% DM) & 3.10 & 1.48 \\
\hline Neutral detergent fiber (\% DM) & 25.14 & 66.46 \\
\hline Acid detergent fiber (\% DM) & 15.17 & 40.93 \\
\hline Total carbohydrates $(\% \mathrm{DM})^{1}$ & 70.82 & 82.22 \\
\hline Non-fibrous carbohydrates $(\% \mathrm{DM})^{2}$ & 38.14 & 15.22 \\
\hline Total digestible nutrients $(\% \mathrm{DM})^{2}$ & 73.77 & 66.34 \\
\hline Metabolizable energy $(\mathrm{Mcal} / \mathrm{kg} \mathrm{DM})^{2}$ & 2.66 & 2.39 \\
\hline Calcium $(\% \mathrm{DM})$ & 1.72 & 0.85 \\
\hline Phosphorus (\% DM) & 0.45 & 0.45 \\
\hline
\end{tabular}

${ }^{1}$ Obtained from the equation proposed by Sniffen et al. (1992). ${ }^{2}$ Obtained from the equation proposed by NRC (2001). 
Slaughter was conducted according to the normal procedures of a commercial slaughterhouse and occurred within two weeks of kids reaching 120 days of age. Mean age at slaughter was 128.4 \pm 7.9 days, and mean body weight was $23.14 \mathrm{~kg}$. Animals were slaughtered after fasting from solids for 16 hours, with pre-fasting and post-fasting weighing to obtain live weight and live weight at slaughter, respectively. The carcass was obtained after separation of the head, viscera, and legs at the carpal-metacarpal and metatarsal-tarsal joints. The carcasses were kept in a cold chamber with forced air at $5{ }^{\circ} \mathrm{C}$ for 24 hours and then weighed to obtain the weight of the cold carcass.

Carcasses were longitudinally sectioned, yielding left half carcasses with an average weight of $5.09 \mathrm{~kg}$ and a range of 2.0 to $9.0 \mathrm{~kg}$. They were then divided into five cuts (YÁÑEZ et al., 2007), leg, loin, rib, shoulder, and neck, which were then weighed, frozen at $-20^{\circ} \mathrm{C}$, and subsequently thawed and dissected into muscle, bone, fat, and other tissues (including connective tissue, lymph nodes, nerves, blood vessels, and tendons).

To study growth, we used the allometric equation proposed by Huxley (1932), $\mathrm{Y}=\mathrm{aX}$, in which $\mathrm{Y}$ is the weight of the parameter whose development is being investigated; $\mathrm{X}$ is the weight of the whole of which the parameter is a part; ' $a$ ' is a fractional coefficient that represents the value of $\mathrm{Y}$ when $\mathrm{X}$ equals 1 ( $\mathrm{a}=$ intercept), having no biological significance; and $b$ is the allometric coefficient, which is used to measure the development of an organ, tissue, or part in a whole. If $b=1$, growth is termed intermediate or isogonic, indicating that the growth rates of $Y$ and $\mathrm{X}$ are similar for the being interval considered. When $b \neq 1$, growth is called heterogonic, and development may be late $(b>1)$ or early $(b<1)$.
For testing of the hypothesis that $\mathrm{b}=1$ we used the $t$ test, setting a significance level of $5 \%$ and calculating $t$ as $(\mathrm{b}-1) / \mathrm{s}(\mathrm{b})$, where $\mathrm{s}(\mathrm{b})$ is the standard deviation of $b$. The SAEG software $v$. 8.0 (UFV, 2000) was used for statistical analysis.

\section{Results and Discussion}

The analysis of tissue growth relative to kid half carcass weight revealed early growth of bone tissue, intermediate growth of muscle, and late growth of adipose tissue, except in the first generation of crosses with the Boer breed, where we observed early development of muscle tissue in the carcass (Table 3). However, the superior muscle profile in the $1 / 2$ BA group was not evident in the $3 / 4$ BA group, a result that may be related to the breed of dam or to first-cross hybrid vigor in the $1 / 2 \mathrm{BA}$ kids. According to Browning Junior et al. (2012), breed of dam can be a significant source of variation for carcass weight.

In a carcass study of kids with characteristics identical to the ones in the present study and slaughtered at a mean age of 110 days, Gomes et al. (2011) observed that the Boer $\times$ Alpine cross exhibited reduced carcass length and increased fat cover and total amount of body tissues. These results suggest that although the Boer breed may not stand out relative to other meat producing breeds (BROWNING JUNIOR et al., 2011, 2012), producing first-cross kids using Boer sires may increase growth and improve carcass characteristics of dairy kids destined for meat production compared to other mating options.

Overall, fat tissue had the highest variation coefficient. According to Rosa et al. (2005), this is the tissue with the greatest variability in both quantity and distribution. The growth of bone and muscle tissues was not affected by finishing system, 
and for both of these tissues growth was considered to be intermediate (Table 4). The smaller live weight at slaughter $(\mathrm{FS} 1=19.01 ; \mathrm{FS} 2=27.27)$ obtained from animals finished on pasture (RODRIGUES, 2009) indicates that slaughter occurred before any decline in growth rate, as described by Owens et al. (1993), wherein the fat is deposited in a higher proportion relative to other tissues. Thus, the deposition of adipose tissue was considered to occur late in these animals, while in the feedlot this deposition occurred earlier, as shown by the larger proportion of fat tissue exhibited by animals in the feedlot treatment, and it was synchronized with carcass growth.

Table 3. Allometric equations of tissue growth relative to half carcass weight (HCW) of kids from five breed types.

\begin{tabular}{|c|c|c|c|c|c|}
\hline Tissues & Breed type $^{1}$ & Regression equation & $\mathrm{b}$ & CV (\%) & $\mathrm{R}^{2}(\%)$ \\
\hline \multirow{5}{*}{ Bone } & Alpine & $\mathrm{Y}=0.37962 \mathrm{HCW}^{0.74502}$ & $\mathrm{~b}<1$ & 8.2 & 90.5 \\
\hline & $1 / 2 \mathrm{BA}$ & $\mathrm{Y}=0.37801 \mathrm{HCW}^{0.70055}$ & $\mathrm{~b}<1$ & 12.4 & 72.6 \\
\hline & $1 / 2$ ANA & $\mathrm{Y}=0.35753 \mathrm{HCW}^{0.73602}$ & $\mathrm{~b}<1$ & 12.9 & 77.5 \\
\hline & $3 / 4 \mathrm{BA}$ & $\mathrm{Y}=0.46127 \mathrm{HCW}^{0.52130}$ & $\mathrm{~b}<1$ & 10.7 & 65.1 \\
\hline & $\mathrm{TC}$ & $\mathrm{Y}=0.34715 \mathrm{HCW}^{0.75141}$ & $\mathrm{~b}<1$ & 5.7 & 94.8 \\
\hline \multirow{5}{*}{ Muscle } & Alpine & $\mathrm{Y}=0.65319 \mathrm{HCW}^{0.93359}$ & $b=1$ & 4.4 & 98.0 \\
\hline & $1 / 2 \mathrm{BA}$ & $\mathrm{Y}=0.68402 \mathrm{HCW}^{0.91150}$ & $\mathrm{~b}<1$ & 3.1 & 98.6 \\
\hline & $1 / 2$ ANA & $\mathrm{Y}=0.64438 \mathrm{HCW}^{0.95571}$ & $b=1$ & 9.0 & 92.2 \\
\hline & $3 / 4 \mathrm{BA}$ & $\mathrm{Y}=0.58164 \mathrm{HCW}^{1.01499}$ & $b=1$ & 3.1 & 98.7 \\
\hline & $\mathrm{TC}$ & $\mathrm{Y}=0.64197 \mathrm{HCW}^{0.96541}$ & $b=1$ & 5.6 & 96.8 \\
\hline \multirow{5}{*}{ Fat } & Alpine & $\mathrm{Y}=0.01516 \mathrm{HCW}^{2.12108}$ & $\mathrm{~b}>1$ & 31.3 & 79.4 \\
\hline & $1 / 2 \mathrm{BA}$ & $\mathrm{Y}=0.02822 \mathrm{HCW}^{1.89147}$ & $b>1$ & 29.2 & 78.3 \\
\hline & $1 / 2$ ANA & $\mathrm{Y}=0.01356 \mathrm{HCW}^{2.15448}$ & $b>1$ & 23.3 & 88.8 \\
\hline & $3 / 4 \mathrm{BA}$ & $\mathrm{Y}=0.04982 \mathrm{HCW}^{1.61716}$ & $b>1$ & 25.6 & 76.0 \\
\hline & $\mathrm{TC}$ & $\mathrm{Y}=0.05612 \mathrm{HCW}^{1.44641}$ & $b>1$ & 22.6 & 84.1 \\
\hline
\end{tabular}

${ }^{1}$ Breed types: A (Alpine); $1 / 2$ BA (1/2 Boer + 1/2 Alpine); $1 / 2$ ANA (1/2 Anglo Nubian + 1/2 Alpine); $3 / 4$ BA ( $3 / 4$ Boer + 1/4 Alpine); TC (1/2 Anglo Nubian $+1 / 4$ Boer $+1 / 4$ Alpine).

$\mathrm{b}$, allometric coefficient; $\mathrm{CV}$, coefficient of variation; $\mathrm{R}^{2}$, coefficient of determination.

Table 4. Allometric equations of tissue growth relative to half carcass weight (HCW) of kids finished in two finishing systems: in pasture with does (FS1) and weaned in a feedlot (FS2).

\begin{tabular}{|c|c|c|c|c|}
\hline & Regression equation & $\mathrm{b}$ & $\mathrm{CV}(\%)$ & $\mathrm{R}^{2}(\%)$ \\
\hline \multicolumn{5}{|l|}{ FS1 } \\
\hline Bone & $\mathrm{Y}=0.31444 \mathrm{HCW}^{0.85740}$ & $\mathrm{~b}=1$ & 10.0 & 78.1 \\
\hline Muscle & $\mathrm{Y}=0.64089 \mathrm{HCW}^{0.95813}$ & $b=1$ & 5.6 & 93.6 \\
\hline Fat & $\mathrm{Y}=0.02415 \mathrm{HCW}^{1.89657}$ & $b>1$ & 39.8 & 49.0 \\
\hline \multicolumn{5}{|l|}{ FS2 } \\
\hline Bone & $\mathrm{Y}=0.26341 \mathrm{HCW}^{0.89020}$ & $\mathrm{~b}=1$ & 10.1 & 74.6 \\
\hline Muscle & $\mathrm{Y}=0.60561 \mathrm{HCW}^{0.98558}$ & $\mathrm{~b}=1$ & 5.4 & 92.7 \\
\hline Fat & $\mathrm{Y}=0.07787 \mathrm{HCW}^{1.30427}$ & $\mathrm{~b}=1$ & 23.2 & 55.3 \\
\hline
\end{tabular}

$\mathrm{b}$, allometric coefficient; $\mathrm{CV}$, coefficient of variation; $\mathrm{R}^{2}$, coefficient of determination. 
In both males and females, bone growth occurred early, whereas fat was deposited later in relation to the half carcass weight (Table 5). The growth of muscle tissue was synchronized with carcass development in males but occurred early in females. This result indicates that at the time of slaughter, females had completed the deposition of muscle in the carcass and from this point on they would gain mostly fat, wheareas in males muscle tissue was still under development, suggesting that males could have been slaughtered at an older age.
Similarly, Yáñez et al. (2009) evaluated the relative growth of male Saanen kids and found early bone growth, intermediate growth of muscle tissue, and late growth of fat. According to these authors, gender is a primary factor in determining important carcass characteristics, including deposition of tissues and the proportion of commercial cuts. According to Bonvillani et al. (2010), females usually have greater fat deposition and consequently a higher marbling score compared to males.

Table 5. Allometric equations of tissue growth relative to half carcass weight (HCW) of male and female kids.

\begin{tabular}{|c|c|c|c|c|}
\hline & Regression equation & $\mathrm{b}$ & $\mathrm{CV}(\%)$ & $\mathrm{R}^{2}(\%)$ \\
\hline \multicolumn{5}{|l|}{ Male } \\
\hline Bone & $\mathrm{Y}=0.41348 \mathrm{HCW}^{0.67743}$ & $b<1$ & 7.4 & 87.4 \\
\hline Muscle & $\mathrm{Y}=0.61748 \mathrm{HCW}^{0.98448}$ & $b=1$ & 3.8 & 98.2 \\
\hline Fat & $\mathrm{Y}=0.02107 \mathrm{HCW}^{1.91977}$ & $b>1$ & 22.7 & 85.4 \\
\hline \multicolumn{5}{|l|}{ Female } \\
\hline Bone & $\mathrm{Y}=0.41109 \mathrm{HCW}^{0.60194}$ & $b<1$ & 11.1 & 71.8 \\
\hline Muscle & $\mathrm{Y}=0.71897 \mathrm{HCW}^{0.86976}$ & $b<1$ & 6.4 & 94.1 \\
\hline Fat & $\mathrm{Y}=0.02574 \mathrm{HCW}^{2.02750}$ & $b>1$ & 20.9 & 88.7 \\
\hline
\end{tabular}

$\mathrm{b}$, allometric coefficient; $\mathrm{CV}$, coefficient of variation; $\mathrm{R}^{2}$, coefficient of determination.

\section{Conclusions}

The production of $1 / 2$ Boer $+1 / 2$ Alpine kids increased growth of muscle tissue compared to the other breed types studied, and thus this cross can improve carcass characteristics of dairy kids for meat production. Animals finished on pasture had late fat deposition. Females exhibited early growth of muscle tissue.

\section{References}

AL-OWAIMER, A.; SULIMAN, G.; EL-WAZIRY, A.; METWALLY, H.; ABOUHEIF, M. Allometric growth patterns of body and carcass components in Ardhi Goat. International Journal of Animal and Veterinary Advances, Reading, v. 5, n. 5, p. 183-189, 2013.

BONVILLANI, A.; PEÑA, F.; GEA, G.; GÓMEZ, G.; PETRYNA, A.; PEREA, J. Carcass characteristics of Criollo Cordobés kid goats under an extensive management system: Effects of gender and liveweight at slaughter. Meat Science, Barking, v. 86, n. 3, p. 651-659, 2010.

BROWNING JUNIOR, R.; LEITE-BROWNING, M. L.; BYARS JUNIOR, M. Reproductive and health traits among Boer, Kiko, and Spanish meat goat does under humid, subtropical pasture conditions of the southeastern United States. Journal of Animal Science, Champaign, v. 89, n. 3, p. 648-660, 2011.

BROWNING JUNIOR, R.; PHELPS, O.; CHISLEY, C.; GETZ, W. R.; HOLLIS, T.; LEITE-BROWNING, M. L. Carcass yield traits of kids from a complete diallel of Boer, Kiko, and Spanish meat goat breeds semiintensively managed on humid subtropical pasture. Journal of Animal Science, Champaign, v. 90, n. 3, p. 709-722, 2012.

GOMES, H. F. B.; MENEZES, J. J. L.; GONÇALVES, H. C.; CAÑIZARES, G. I. L.; MEDEIROS, B. B. L.; POLIZEL NETO, A.; LOURENÇON, R. V.; CHÁVARI, 
A. C. T. Características de carcaça de caprinos de cinco grupos raciais criados em confinamento. Revista Brasileira de Zootecnia, Viçosa, MG, v. 40, n. 2, p. 411417, 2011.

HUXLEY, J. S. Problems of relative growth. London: Methuen, 1932. $276 \mathrm{p}$.

MADRUGA, M. S.; NARAIN, N.; DUARTE, T. F.; SOUSA, W. H.; GALVÃO, M. S.; CUNHA, M. G. G.; RAMOS, J. L. F. Características químicas e sensoriais de cortes comerciais de caprinos SRD e mestiços de Boer. Ciência e Tecnologia de Alimentos, Campinas, v. 25, n. 4, p. 713-719, 2005.

MONTE, A. L. S.; SELAIVE-VILLARROEL, A. B.; PÉREZ, J. R. O.; ZAPATA, J. F. F.; BESERRA, F. J.; OLIVEIRA, A. N. Rendimento de cortes comerciais e composição tecidual da carcaça de cabritos mestiços. Revista Brasileira de Zootecnia, Viçosa, MG, v. 36, n. 6, p. 2127-2133, 2007.

NATIONAL RESEARCH COUNCIL - NRC. Nutrient requirements of diary cattle. $7^{\text {th }} \mathrm{ed}$. Washington: National Academic Press, 2001. 387 p.

OWENS, F. N.; DUBESKI, P.; HANSON, C. F. Factors that alter the growth and development of ruminants. Journal of Animal Science, Champaign, v. 71, n. 11, p. 3138-3150, 1993.

PEREIRA FILHO, J. M.; RESENDE, K. T.; TEIXEIRA, I. A.; SILVA SOBRINHO, A. G.; YÁÑEZ, E. A.; FERREIRA, A. C. D. Características da carcaça e alometria dos tecidos de cabritos F1 Boer $\times$ Saanen. Revista Brasileira de Zootecnia, Viçosa, MG, v. 37, n. 5, p. 905-912, 2008.
RODRIGUES, L. Sistemas de produção de caprinos de leite e carne em pasto ou confinamento. 2009. Tese (Doutorado em Zootecnia) - Faculdade de Medicina Veterinária e Zootecnia, Universidade Estadual Paulista, Botucatu.

ROSA, G. T.; PIRES, C. C.; SILVA, J. H. S.; MOTTA, O. S. Crescimento alométrico de osso, músculo e gordura em cortes da carcaça de cordeiros Texel segundo os métodos de alimentação e peso de abate. Ciência Rural, Santa Maria, RS, v. 35, n. 4, p. 870-876, 2005.

SILVA, D. J.; QUEIROZ, A. C. Análise de alimentos: métodos químicos e biológicos. 3. ed. Viçosa, MG: Universidade Federal de Viçosa, 2002. 165 p.

SNIFFEN, C. J.; O'CONNOR, J. D.; VAN SOEST, P. J.; FOX, D. G.; RUSSELL, J. B. A net carbohydrate and protein system for evaluating cattle diets: II. Carbohydrate and protein availability. Journal of Animal Science, Champaign, v. 70, n. 11, p. 3562-3577, 1992.

UNIVERSIDADE FEDERAL DE VIÇOSA - UFV. Sistema de análises estatísticas e genéticas - SAEG. Versão 8. 0. Viçosa, MG, 2000. 142 p.

YÁÑEZ, E. A.; RESENDE, K. T.; FERREIRA, A. C. D.; MEDEIROS, A. N.; SILVA SOBRINHO, A. G.; ARTONI, S. M. B. Effects of feed restriction on yield, retail cuts and tissue composition of carcass of Saanen kids. Revista Brasileira de Zootecnia, Viçosa, MG, v. 36, n. 3, p. 666-673, 2007.

YÁÑEZ, E. A.; RESENDE, K. T.; FERREIRA, A. C. D.; PEREIRA FILHO, J. M.; MEDEIROS, A. N.; TEIXEIRA, I. A. M. A. Relative development of tissues, commercial meat cuts and live weight components in Saanen goats. Revista Brasileira de Zootecnia, Viçosa, MG, v. 38, n. 2, p. 366-373, 2009. 
